Edyta Małecka-Ziembińska

\title{
LUKA W PODATKU OD TOWARÓW I USŁUG ORAZ SPOSOBY JEJ OGRANICZANIA
}

\section{Wprowadzenie}

Z wprowadzeniem w Polsce z dniem 5 lipca 1993 r. podatku od towarów i usług wiązano wielkie nadzieje. Sądzono bowiem, że przyczyni się on do spadku oszustw podatkowych w obrocie towarami i usługami (dzięki samokontroli podatników) oraz do wzrostu dochodów publicznych. Tymczasem podatek ten z jednej strony stanowi podstawowy trzon dochodów budżetu państwa, a z drugiej strony jego wydajność fiskalna jest poważnie zagrożona licznymi - o dużej skali finansowej - oszustwami podatkowymi. W ocenie organów państwa „szeroko rozumiana przestępczość podatkowa, w szczególności dotycząca podatku VAT oraz podatku akcyzowego, generuje najwyższe straty dla budżetu państwa i godzi w jego bezpieczeństwo ekonomiczne"2. Z komparatystyki międzynarodowej w zakresie rozmiarów szarej strefy gospodarki oraz wpływu zmiennych ją warunkujących wynika też, że w Polsce wpływ podatków pośrednich, a więc w tym badanego podatku, na jej rozmiary jest wyraźnie wyższy niż średnio w uwzględnionych w badaniu 37 wysoko rozwiniętych państwach ${ }^{3}$.

Podatek od towarów i usług, będący polskim wariantem podatku od wartości dodanej (VAT), jest podatkiem wielofazowym, naliczanym w każdej fazie obrotu od całości obrotu. Opodatkowanie wartości dodanej jest zapewnione poprzez przyznanie prawa do odliczenia od podatku należnego - podatku naliczonego przy nabyciu dóbr służących działalności gospodarczej. Opodatkowanie każdej fazy produkcji i dystrybucji z jednej strony przyspiesza pobór tego podatku, z drugiej natomiast komplikuje podatek i stwarza więcej okazji do nadużyć. W państwach Unii Europejskiej podatek od wartości dodanej jest zharmonizowany, przy czym w zakresie

1 Dr hab. Edyta Małecka-Ziembińska, Katedra Finansów Publicznych, Wydział Ekonomii, Uniwersytet Ekonomiczny w Poznaniu.

2 MSW, Raport o stanie bezpieczeństwa w Polsce w 2014 roku, 2015, s. 166, https://bip.mswia.gov.pl/ bip/raport-o-stanie-bezpie/18405, Raport-o-stanie-bezpieczenstwa.html [dostęp 1.06.2016]

3 F. Schneider, K. Raczkowski, Sfera nieoficjalna w gospodarce, „Infos” 2013, nr 21, s. 3. 
obrotu wewnątrzwspólnotowego, co do zasady, charakteryzuje się opodatkowaniem transakcji nie w „miejscu pochodzenia towarów”, lecz w „miejscu przeznaczenia towarów". W warunkach jednolitego rynku wewnętrznego, przy braku granic celno-podatkowych naraża to państwa członkowskie na ubytek dochodów budżetowych na skutek wyłudzania VAT. Celem artykułu jest zatem przedstawienie szacunków luki w VAT w państwach UE w latach 2000-2013, a w odniesieniu do Polski dodatkowo zidentyfikowane zostaną przyczyny jej występowania oraz podejmowane działania mające na celu ograniczenie jej rozmiarów.

\section{Luka w VAT i przyczyny jej występowania}

W polskim prawodawstwie pojęcie „luki podatkowej” nie zostało zdefiniowane. Termin ten powstał, a następnie opracowano metodykę jego wyznaczania m.in. na potrzeby raportów, badań i analiz porównawczych takich organizacji międzynarodowych, jak OECD czy IMF*. Według amerykańskiej Internal Revenue Service luka podatkowa pozwala zmierzyć skalę, w jakiej podatnicy nie składają zeznań podatkowych i nie płacą podatku na czas 5 . Jest ona definiowana jako różnica pomiędzy kwotą podatków, które powinny zostać zapłacone, a kwotą, która faktycznie trafia do budżetu państwa ${ }^{6}$.

Przyczyn występowania luki podatkowej jest wiele i są one różnie klasyfikowane. Składają się bowiem na nią obserwowalne zaległości podatkowe oraz nieobserwowalne ubytki dochodów podatkowych, wynikające z istnienia m.in. szarej strefy w gospodarce. Jest ona również rezultatem oszustw podatkowych oraz działań optymalizacyjnych (legalnych i nielegalnych) podejmowanych w celu uniknięcia bądź zmniejszenia podatku, a także wynikiem bankructw czy błędów statystycznych7.

4 Odpowiedź z dnia 5.10.2012 r. Pana Macieja Grabowskiego podsekretarza stanu w Ministerstwie Finansów - z upoważnienia ministra - na interpelację nr $8642 \mathrm{w}$ sprawie luki podatkowej w podatku od towarów i usług oraz strat finansowych w związku z nią poniesionych, http://sejm.gov.pl/sejm7.nsf/interpelacja.xsp?typ=INT\&nr=8642\&view=null [dostęp 17.05.2016].

5 IRS, Understanding the Tax Gap, https://www.irs.gov/uac/understanding-the-tax-gap, 2005 [dostęp 17.05.2016].

6 PWC i IBS, Straty Skarbu Państwa w VAT (maj 2013 roku), s. 5, www.pwc.pl/pl/publikacje/assets/pwc_ straty_skarbu_panstwa_w_vat.pdf [dostęp 15.02.2016].

7 Informacja o działaniach podjętych przez Polskę $w$ celu realizacji rekomendacji Rady w ramach procedury nadmiernego deficytu. Załącznik 2 - Działania zwiększajace stopień przestrzegania przepisów podatkowych i poprawiajace efektywność administracji podatkowej w latach 2014-2017, s. 18, http://www.mf.gov. $\mathrm{pl} /$ documents/764034/1002171/EDP+raport+2014.04.pdf [dostęp 1.06.2016]. 
W dniu 27 listopada 2014 r. rozpoczęła prace grupa robocza w ramach programu Fiscalis - Tax Gap project group, która ma za zadanie wypracować przewodnik dobrych praktyk w szacowaniu luki podatkowej, w tym zwłaszcza w VAT. W pracach grupy uczestniczą przedstawiciele 15 państw członkowskich, w tym z Polski. W marcu $2016 \mathrm{r}$. opublikowany został raport przedstawiający zaawansowanie prac nad szacowaniem luki podatkowej w tych państwach ${ }^{8}$. Wynika $z$ niego, że obecnie w Polsce w Ministerstwie Finansów trwają prace nad metodyką szacowania, w tym również prognozowania luki podatkowej w VAT. Celem tych działań jest stworzenie miernika statystycznego pozwalającego na monitorowanie w czasie ściągalności podatków, a tym samym efektywności systemu i administracji podatkowej ${ }^{9}$. Wstępne wyniki, wykorzystywane na razie jedynie w celach wewnętrznych - według oficjalnych informacji - są bliskie szacunkom wykonanym na zlecenie Komisji Europejskiej przez CASE ${ }^{10}$. Szacunki luki w VAT w państwach UE w latach 2000-2013, wykonane przez CASE, zostały przedstawione w tabeli 1.

Luka w VAT w Polsce w 2013 r. stanowiła 27\% potencjalnych wpływów z tego podatku i w stosunku do roku poprzedniego wzrosła o 2 pkt. proc., a w stosunku do roku 2011 - aż o 8 pkt. proc. Wielkość realizowanych dochodów z podatku od towarów i usług oraz skala ujawnionych oszustw podatkowych wskazuje, że w latach 2014 i 2015 poziom luki w tym podatku nie uległ istotnemu obniżeniu ${ }^{11}$. Natomiast najniższy poziom luki w VAT w Polsce, średnio wynoszący 6\%, oszacowano dla lat 2005-2008, a więc bezpośrednio po wstąpieniu Polski do UE. Można przypuszczać, że podatnicy dopiero uczyli się wówczas nowych zasad opodatkowania transakcji wewnątrzwspólnotowych i rozpoznawali mechanizmy umożliwiające wyłudzenia tego podatku.

8 EU, The Concept of Tax Gaps. Report on VAT Gap Estimations by Fiscalis Tax Gap Project Group (FPG/041), 2016, http://ec.europa.eu/taxation_customs/resources/documents/common/publications/studies/tgpg report_en.pdf [dostęp 18.05.2016].

9 NIK, Informacja o wynikach kontroli Przeciwdziałanie wprowadzaniu do obrotu gospodarczego faktur dokumentujących czynności fikcyjne, Nr ewid. 24/2016/P/15/011/KBF, Warszawa 2016, s. 35.

10 CASE, Study to quantify and analyse the VAT Gap in the EU-27 Member States. Final Report, 2013, http://ec.europa.eu/taxation_customs/resources/documents/common/publications/studies/vat-gap.pdf [dostęp 15.02.2016]; CASE, 2012 Update Report to the Study to quantify and analyse the VAT Gap in the EU-27 Member States, 2014, http://ec.europa.eu/taxation_customs/resources/documents/common/publications/studies/vat_gap2012.pdf [15.02.2016]; CASE, Study to quantify and analyse the VAT Gap in the EU Member States. 2015 Report, http://ec.europa.eu/taxation_customs/resources/documents/common/publications/studies/vat_gap2013.pdf [dostęp 17.05.2016]; EU, op.cit., s. 81.

11 NIK, Informacja o wynikach..., 2016, op.cit., s. 35. 
Tabela 1. Luka w VAT w państwach UE w latach 2000-2013 (jako \% dochodów potencjalnych)

\begin{tabular}{|c|c|c|c|c|c|c|c|c|c|c|c|c|c|c|c|}
\hline Państwo & 유 & ర్ণ & ণ్రి & ஜి & ర્ટి & 足 & $\stackrel{\text { ¿ }}{\circ}$ & & 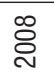 & 유 & 음 & $\bar{\sigma}$ & ָั & $\stackrel{m}{\sim}$ & Średnia \\
\hline Austria & 9 & 11 & 8 & 11 & 11 & 11 & 14 & 13 & 13 & 9 & 12 & 13 & 11 & 11 & 11 \\
\hline Belgia & 9 & 14 & 11 & 15 & 13 & 13 & 13 & 11 & 15 & 13 & 11 & 11 & 11 & 11 & 12 \\
\hline Bułgaria & 23 & 26 & 34 & 23 & 14 & 10 & 7 & 12 & 4 & 25 & 22 & 24 & 19 & 17 & 19 \\
\hline Czechy & 30 & 29 & 29 & 31 & 12 & 10 & 16 & 19 & 23 & 23 & 26 & 20 & 24 & 22 & 22 \\
\hline Dania & 11 & 11 & 10 & 9 & 10 & 9 & 9 & 9 & 11 & 8 & 8 & 9 & 9 & 9 & 9 \\
\hline Estonia & 13 & 16 & 17 & 18 & 24 & 14 & 11 & 9 & 19 & 10 & 11 & 12 & 13 & 17 & 15 \\
\hline Finlandia & 12 & 13 & 13 & 13 & 14 & 12 & 12 & 15 & 15 & 3 & 7 & 4 & 3 & 4 & 10 \\
\hline Francja & 11 & 13 & 15 & 15 & 14 & 14 & 15 & 14 & 16 & 13 & 8 & 7 & 9 & 9 & 12 \\
\hline Grecja & 25 & 22 & 23 & 27 & 28 & 31 & 32 & 32 & 29 & 34 & 30 & 38 & 33 & 34 & 30 \\
\hline Hiszpania & 6 & 8 & 10 & 7 & 5 & 1 & 1 & 10 & 22 & 35 & 12 & 17 & 17 & 17 & 12 \\
\hline Holandia & 9 & 8 & 7 & 6 & 3 & 3 & 2 & 0 & 4 & 8 & 1 & 4 & 4 & 4 & 5 \\
\hline Irlandia & 9 & 1 & 4 & 6 & 3 & 7 & 7 & 9 & 11 & 14 & 11 & 14 & 11 & 11 & 8 \\
\hline Litwa & 30 & 34 & 33 & 38 & 42 & 36 & 33 & 29 & 29 & 44 & 38 & 37 & 37 & 38 & 35 \\
\hline Łotwa & 16 & 21 & 22 & 22 & 23 & 15 & 11 & 11 & 26 & 43 & 35 & 38 & 34 & 30 & 25 \\
\hline Luksemburg & 15 & 15 & 13 & 13 & 10 & 9 & 8 & 11 & 12 & 3 & 3 & 4 & 5 & 5 & 9 \\
\hline Malta & 17 & 17 & 16 & 15 & 20 & 9 & 10 & 13 & 12 & 24 & 28 & 29 & 31 & 26 & 19 \\
\hline Niemcy & 11 & 14 & 13 & 13 & 13 & 13 & 12 & 14 & 13 & 9 & 10 & 11 & 11 & 11 & 12 \\
\hline Polska & 17 & 21 & 18 & 18 & 17 & 9 & 5 & 2 & 9 & 21 & 18 & 19 & 25 & 27 & 16 \\
\hline Portugalia & 3 & 5 & 6 & 6 & 7 & 3 & 6 & 7 & 9 & 15 & 12 & 13 & 9 & 9 & 8 \\
\hline Rumunia & 42 & 49 & 39 & 39 & 45 & 34 & 37 & 36 & 37 & 50 & 45 & 42 & 43 & 41 & 41 \\
\hline Stowacja & 27 & 27 & 28 & 21 & 24 & 20 & 27 & 31 & 30 & 34 & 36 & 31 & 39 & 35 & 29 \\
\hline Stowenia & 4 & 5 & 5 & 6 & 6 & 5 & 5 & 7 & 9 & 13 & 11 & 9 & 9 & 6 & 7 \\
\hline Szwecja & 6 & 6 & 6 & 5 & 4 & 4 & 5 & 4 & 3 & 3 & 3 & 4 & 5 & 4 & 4 \\
\hline W. Brytania & 12 & 13 & 13 & 10 & 11 & 11 & 13 & 13 & 15 & 13 & 12 & 10 & 11 & 10 & 12 \\
\hline Węgry & 22 & 28 & 30 & 26 & 23 & 27 & 27 & 24 & 26 & 24 & 24 & 23 & 24 & 24 & 25 \\
\hline Wlochy & 23 & 25 & 24 & 28 & 29 & 28 & 24 & 23 & 26 & 36 & 29 & 32 & 32 & 34 & 28 \\
\hline UE-26a & 16 & 17 & 17 & 17 & 16 & 14 & 14 & 15 & 17 & 20 & 18 & 18 & 18 & 18 & 17 \\
\hline
\end{tabular}

${ }^{a}$ Bez Cypru i Chorwacji; średnia arytmetyczna (obliczenia własne).

Źródło: CASE, Study to quantify and analyse the VAT Gap in the EU-27 Member States. Final Report, 2013, s. 123, http://ec.europa.eu/taxation_customs/resources/documents/common/publications/studies/vat-gap.pdf; CASE, Study to quantify and analyse the VAT Gap in the EU Member States. 2015 Report, 2015, s. 63, http://ec.europa. eu/taxation_customs/resources/documents/common/publications/studies/vat_gap2013.pdf

Uchylanie się od VAT występuje w całej UE, prowadząc do znacznych ubytków w dochodach budżetowych, naruszenia zasady sprawiedliwego opodatkowania, a także zakłócenia warunków konkurencji12. W latach 2000-2013 dla 26 państw UE

12 Ibidem, s. 7. 
(bez Cypru i Chorwacji) luka w VAT najniższe rozmiary osiągnęła w latach 2005 i 2006 - 14\%, najwyższe w roku 2009 - 20\%, średnio wynosząc 17\%. Najniższą lukę w VAT w tym okresie - poniżej 10\% - oszacowano dla Szwecji (4\%), Holandii (5\%), Słowenii (7\%), Irlandii (8\%), Portugalii (8\%), Danii (9\%) i Luksemburga (9\%). Natomiast najwyższe jej rozmiary - 30\% i więcej - oszacowano dla Rumunii (41\%), Litwy (35\%) oraz Grecji (30\%).

Luka podatkowa jest wielkością szacowaną, bazującą na wielu danych statystycznych, w tym na takich wielkościach, jak szacunki szarej strefy, stąd jej poziom należy interpretować z ostrożnością. Większą wagę przypisuje się natomiast do jej zmian $\mathrm{w}$ czasie $^{13}$. Niestety, zaprezentowane w tabeli 1 dane wskazują na niepokojący trend wzrostu rozmiarów luki w VAT w Polsce. Ponadto z wyjątkiem lat 2005-2008 jej rozmiary utrzymywały się na poziomie wyższym niż średnia wielkość tego zjawiska w państwach UE. Świadczy to „o niewystarczającej efektywności polskiego systemu podatkowego i potrzebie wprowadzenia nowych rozwiązań mających na celu ograniczenie oszustw podatkowych" ${ }^{14}$.

Duża luka w podatku od towarów i usług wynika zarówno ze zorganizowanego na znaczną skalę procederu wyłudzania tego podatku, jak i z działalności gospodarczej prowadzonej w szarej strefie. Do rozpoznanych mechanizmów oszustw wykorzystywanych w celu zaniżania zobowiązań podatkowych w podatkach pośrednich, w tym w VAT, należy zaliczyć m.in.: przestępstwa karuzelowe, wystawianie pustych faktur, usuwanie towaru spod dozoru celnego, zaniżanie wartości celnej. Charakterystycznymi działaniami podejmowanymi w ramach tych mechanizmów są m.in.: wykorzystanie znikającego podatnika, fałszowanie dokumentacji celnej i skarbowej, nadużycia w funkcjonowaniu tax free czy wykorzystanie słabych punktów w zakresie wymiany informacji między organami administracji państwowej ${ }^{15}$. W ostatnim czasie obserwowany jest także wzrost przestępczości podatkowej z udziałem obcokrajowców pochodzących z państw UE, którzy rejestrują w Polsce podmioty gospodarcze i wykorzystują polski system podatkowy do czerpania korzyści z nienależnych zwrotów VAT ${ }^{16}$.

13 Informacja o działaniach..., op.cit., s. 18.

14 NIK, Informacja o wynikach..., 2016, op.cit., s. 13.

15 Zwalczanie uchylania się od VAT oraz zapobieganie jego wyłudzaniu wymaga ścisłej współpracy między organami administracyjnymi każdego państwa członkowskiego właściwymi do stosowania przepisów w tym zakresie. Tymczasem na niedostatki polskiej administracji podatkowej w tym obszarze już w $2010 \mathrm{r}$. zwracała uwagę NIK. NIK, Informacja o wynikach kontroli opodatkowania transakcji wewnątrzwspólnotowych podatkiem od towarów i usług oraz egzekwowania zaległości w VAT, Nr ewid. 16/2010/P09023/KBF, Warszawa 2010.

16 MSW, Raport o stanie..., 2015, op.cit., s. 166 i 167. 
Najbardziej szkodliwe dla budżetu państwa oszukańcze praktyki, ujawnione przez organy kontroli skarbowej, dotyczyły jednak wyłudzania zwrotów VAT w związku z rzekomymi dostawami wewnątrzwspólnotowymi oraz unikania płacenia tego podatku od nabyć wewnątrzwspólnotowych ${ }^{17}$. Problem jest o tyle istotny, że liczba podatników rejestrujących się na potrzeby takich transakcji rośnie. Przykładowo, na koniec grudnia 2014 r. w urzędach skarbowych zarejestrowanych było 1620,3 tys. podatników VAT, w tym 744,5 tys. podatników VAT UE. Na koniec czerwca 2015 r. liczby te wyniosły odpowiednio 1628,9 tys. oraz 788,5 tys. ${ }^{18}$

W przypadku importu, obok przemytu towarów, najbardziej rozpowszechnioną formą oszustwa celnego i podatkowego było zaniżanie wartości celnej importowanych towarów, a przez to także cła, podstawy opodatkowania i samego należnego podatku od towarów i usług. Z kolei w przypadku eksportu towarów i usług jedną z form oszustw podatkowych był fikcyjny eksport, który umożliwia oszustom podatkowym otrzymanie zwrotu podatku naliczonego od transakcji eksportowych przeprowadzanych tylko na papierze, czyli takich, które faktycznie nie miały miejsca ${ }^{19}$.

Skuteczna walka z przemytem towarów czy szerzej oszustwami granicznymi jest warunkowana sprawnością służb granicznych. Tymczasem stan organizacji i wyposażenia służb państwowych na przejściach granicy wschodniej ze względu na braki kadrowe, niedobory sprzętu oraz nieodpowiednią infrastrukturę nie nadąża za wzrastającą liczbą osób przekraczających granicę wschodnią (o 46\% w latach 2010-2013), a także wzrastającą liczbą odprawionych pojazdów (o 36,2\% w latach 2010-2013). Przykładowo, ukompletowanie stanu osobowego jednostek Służby Granicznej działających na wschodniej granicy RP wyniosło w 2010 r. - 82,1\%, w 2011 r. - 83,1\%, w 2012 r. - 79,1\%, a w 2013 r. - 83,8\%. Sytuację tę pogarszała jeszcze wysoka absencja (zwolnienia lekarskie) wynosząca statystycznie 24 dni na funkcjonariusza Służby Granicznej w 2013 r. Taki stan skutkuje koniecznością wdrażania procedur awaryjnych, w tym rezygnacji lub okresowej rezygnacji z kontroli szczegółowej, obniżanie poziomu kontroli losowej, łączenie stanowisk kontroli. Działania te wprawdzie przyczyniają się do upłynnienia ruchu, odbywają się jednak ze szkodą dla jakości i efektywności kontroli celnej, a w rezultacie zagrażają interesom fiskalnym państwa ${ }^{20}$

17 Obserwuje się wysoką i rosnącą asymetrię między tym, co państwa UE raportują jako wywóz towarów do Polski, a tym, co Polska raportuje jako przywóz towarów z tych państw. PWC i IBS, op.cit., s. 7.

18 NIK, Informacja o wynikach..., 2016, op.cit., s. 15, 34 i 37.

19 T. Juja, Wydajność fiskalna podatku od towarów i usług w latach 2001-2007, w: Wspótczesne finanse. Stan i perspektywy rozwoju finansów publicznych, red. J. Głuchowski, Wydawnictwo UMK, Toruń 2008, s. 533-542.

20 NIK, Informacja o wynikach kontroli Sprawność działania stużb państwowych na wybranych przejściach granicznych na granicy wschodniej RP, Nr ewid. 207/2014/P14/108/LRZ, Warszawa 2015, s. 7-10. 
$\mathrm{W}$ obrocie krajowym występuje z jednej strony proceder zaniżania należnego VAT oraz podatku do zapłacenia na skutek nierejestrowania obrotu, z drugiej natomiast zawyżanie podatku naliczonego przez niektórych podatników.

Pierwszy proceder najbardziej rozpowszechniony jest w sektorze małych i średnich przedsiębiorstw, a zwłaszcza w ich obrocie z osobami fizycznymi. Do ograniczenia zakresu tego rodzaju szarej strefy przed laty przyczyniały się między innymi ulgi w podatku dochodowym od osób fizycznych, których odliczenie wymagało udokumentowania poniesienia przez podatnika wydatku fakturą wystawioną przez podatnika VAT. W rezultacie ograniczania tych ulg pod hasłem uproszczenia podatku dochodowego od osób fizycznych wzrosły oszustwa w VAT ${ }^{21}$.

Coraz częstsze są też przypadki odliczenia podatku naliczonego od podatku należnego na podstawie fikcyjnych faktur lub faktur wystawionych przez nieistniejące firmy. Wyłudzenia zwrotu VAT są ułatwione, gdyż w Polsce nadal brak jest ogólnokrajowej bazy danych o podatnikach podatku od towarów i usług, dostępnej w każdym momencie dla kontrolerów urzędów i izb skarbowych oraz inspektorów kontroli skarbowej. W 2013 r. organy kontroli skarbowej wykryły fikcyjne faktury na kwotę 19,7 mld zł, w 2014 r. na kwotę 33,7 mld zł, a w 2015 r. już na kwotę 81,9 mld zł. W związku z ustaleniami (na podstawie art. 108 ustawy o podatku od towarów i usług) wymierzyły one odpowiednio 2,3 mld zł w 2013 r., 5,2 mld zł w 2014 r. oraz 4,9 mld zł w I półroczu 2015 r. należnych podatków. Jednak dochody do budżetu państwa $\mathrm{z}$ tego tytułu w latach 2013 i 2014 oraz w I półroczu 2015 r. wyniosły zaledwie 162,3 mln zł, czyli $1,3 \%$ kwot należnych, wymierzonych przez organy kontroli skarbowej. W rezultacie nastąpił gwałtowny wzrost zaległości w VAT, będący konsekwencją z jednej strony wzrostu kwot w wykrytych fakturach fikcyjnych, a z drugiej - niskiej skuteczności odzyskiwania wymierzonych podatków. Zaległości te na przestrzeni półtora roku - z końca 2013 r. do I półrocza 2015 r. - wzrosły prawie trzykrotnie: z około 5 do ponad 14 mld zł. Działania organów kontroli skarbowej, aczkolwiek rzetelne - z trafnością typowania do kontroli wynoszącą często nawet $90 \%$, były jednak przeważnie nieskuteczne, gdyż nie pozwalały wykryć faktycznych organizatorów oszustw podatkowych, a jedynie firmy „słupy”22.

Branżami wysokiego ryzyka oszustw w VAT są branża paliwowa oraz elektroniczna. Ustalenia w tych branżach stanowiły odpowiednio $39,2 \%$ oraz $34,2 \%$ całości ustaleń, będących rezultatem postępowań kontrolnych w zakresie VAT zakończonych w 2015 . $^{23}$ Według raportów Ministerstwa Spraw Wewnętrznych o stanie

21 T. Juja, op.cit., s. 533-542.

22 NIK, Informacja o wynikach..., 2016, op.cit., s. 9 i 36.

23 Ministerstwo Finansów, Sprawozdanie z działalności kontroli skarbowej za 2015 rok, Warszawa 2016, s. 5. 
bezpieczeństwa w Polsce zagrożenie dla interesów finansowych państwa stanowią nieprawidłowości w obrocie nie tylko paliwami, lecz także alkoholem, wyrobami tytoniowymi oraz złomem. Z wyjątkiem złomu, pozostałe grupy wyrobów są jednocześnie wyrobami akcyzowymi, zatem nieprawidłowości w zakresie ich obrotu skutkują także niższymi wpływami z podatku akcyzowego ${ }^{24}$. W kontekście egzekucji zaległości warto podkreślić, że dyrektorzy izb celnych jako organ egzekucyjny podatku od towarów i usług z tytułu importu towarów nadal posiadają mniejsze od naczelników urzędów skarbowych uprawnienia. Nie mogą zabezpieczać należności w trybie i na zasadach określonych w ustawie o postępowaniu egzekucyjnym $\mathrm{w}$ administracji oraz prowadzić egzekucji z nieruchomości ${ }^{25}$. Konieczne jest usprawnienie przebiegu postępowania egzekucyjnego w ogóle, a w odniesieniu do dyrektorów izb celnych - w szczególności. W okresie objętym badaniem pracownicy działów egzekucyjnych izb celnych zarabiali mniej od pracowników wykonujących egzekucję w urzędach skarbowych, różne były też systemy wynagradzania osób zatrudnionych w komórkach egzekucyjnych ${ }^{26}$.

W warunkach postępującej globalizacji zjawisk gospodarczych i rosnącej konkurencji przedsiębiorstw znaczenia nabierają nowoczesne metody sprzedaży, w tym przez internet. Skuteczny i efektywny pobór należnego od takich transakcji podatku od towarów i usług (a także podatku akcyzowego oraz cła) wymaga wyposażenia organów podatkowych i celnych w specjalistyczne narzędzia informatyczne pozwalające monitorować sieci elektroniczne w sposób kompleksowy, z wykorzystaniem możliwości technicznych komputerów. Tymczasem i w tym zakresie identyfikowane są niedostatki polskiej administracji celno-podatkowej ${ }^{27}$.

24 MSW, Raport o stanie bezpieczeństwa w Polsce w 2011 roku, 2012, s. 171, https://bip.mswia.gov. $\mathrm{pl} /$ bip/raport-o-stanie-bezpie/18405, Raport-o-stanie-bezpieczenstwa.html [dostęp 1.06.2016]; MSW, Raport o stanie bezpieczeństwa $w$ Polsce w 2012 roku, 2013, s. 185, https://bip.mswia.gov.pl/bip/raport-o-stanie-bezpie/18405, Raport-o-stanie-bezpieczenstwa.html [dostęp 1.06.2016]; MSW, Raport o stanie bezpieczeństwa w Polsce w 2013 roku, 2014, s. 175, https://bip.mswia.gov.pl/bip/raport-o-stanie-bezpie/18405, Raport-o-stanie-bezpieczenstwa.html [dostęp 1.06.2016]; MSW, Raport o stanie..., 2015, op.cit., s. 165-173.

25 Art. $19 \$ 5$ Ustawy z dnia 17 czerwca 1966 r. o postępowaniu egzekucyjnym w administracji, tekst jedn., DzU 2014, poz. 1619 ze zm.

26 NIK, Egzekwowanie należności podatkowych i celnych przez izby celne, Nr ewid. 48/2013/P12037/KBF, Warszawa 2013, s. 10.

27 NIK Delegatura w Kielcach, Wystapienie pokontrolne (Numer i tytuł kontroli: K/14/009 - Egzekwowanie obowiązków podatkowych i celnych od podmiotów prowadzących handel internetowy), LKI-4111-0103/2014, Kielce 2014, s. 5. 


\section{Działania zmierzające do ograniczenia luki w podatku od towarów i usług}

Wobec dużej skali i rosnącej tendencji luki w podatku od towarów i usług kluczowego znaczenia nabierają działania mające na celu ograniczenie przestępczości $\mathrm{w}$ tym podatku. Podejmowane działania mają charakter legislacyjny, organizacyjny bądź prewencyjny.

Najobszerniejszą grupę stanowią działania z obszaru legislacyjnej interwencji. Przede wszystkim obejmują one wprowadzenie mechanizm odwrotnego obciążenia (reverse charge) oraz solidarną odpowiedzialność podatkową.

Mechanizm odwrotnego obciążenia podatkiem od towarów i usług w przypadku obrotu złomem wprowadzono $\mathrm{z}$ dniem 1 kwietnia $2011 \mathrm{r}{ }^{28} \mathrm{Z}$ dniem 1 lipca tego samego roku został on rozszerzony na obrót odpadami, których odzysk i przetwarzanie stwarzało - co było sygnalizowane przez organizacje przedstawicielskie przedsiębiorców działających w szeroko definiowanej branży złomu - ryzyko wystąpienia nadużyć podatkowych (np. zużyte akumulatory elektryczne, odpady szklane, gumowe i z tworzyw sztucznych) (do ustawy o podatku od towarów i usług został wprowadzony wówczas załącznik nr 11 zawierający wykaz towarów objętych odwrotnym opodatkowaniem). Celem tej zmiany było także usunięcie wątpliwości interpretacyjnych, jakie pojawiły się na gruncie poprzednich przepisów w związku z brakiem ustawowej definicji złomu.

Od 1 października 2013 r. wprowadzono solidarną odpowiedzialność podatkową nabywców towarów wrażliwych za podatek niezapłacony przez sprzedawcę ${ }^{29}$. Dotyczy ona jednak wyłącznie towarów określonych w załączniku nr 13 do ustawy o podatku od towarów i usług, takich jak niektóre wyroby stalowe (nieobjęte mechanizmem odwrotnego obciążenia), paliwa i złoto nieobrobione ${ }^{30}$. Zlikwidowano wówczas również możliwości kwartalnego rozliczania VAT przez podatników dokonujących sprzedaży towarów wrażliwych wymienionych w załączniku nr 13.

Z dniem 1 lipca 2015 r. rozszerzono katalog towarów objętych mechanizmem odwróconego obciążenia o wyroby z kategorii elektroniki (takie jak tablety, notebooki, laptopy, telefony komórkowe, konsole do gier wideo), towary z kategorii złota,

28 Od 1 stycznia 2011 r. takie rozwiązanie wprowadziły Niemcy.

29 Instytucja solidarnej odpowiedzialności podatkowej w VAT została wprowadzona w 19 państwach UE, przy czym w części z nich ujęta została w formie normy generalnej, a w pozostałych państwach - tak jak w Polsce - jej stosowanie zostało ograniczone do określonych kategorii towarów. NIK, Informacja o wynikach..., 2016, op.cit., s. 24.

30 Art. 105a-105d Ustawy z dnia 11 marca 2004 r. o podatku od towarów i usług, tekst jedn., DzU 2011, nr 177, poz. 1054 ze zm. 
nieobrobione plastycznie metale nieżelazne (takie jak aluminium, ołów, cynk, cyna i nikiel) oraz kolejne towary z kategorii stali. Rozszerzono wówczas także zakres stosowania instytucji odpowiedzialności podatkowej na nabywców materiałów eksploatacyjnych do drukarek, niektórych towarów ze stali, niektórych metali szlachetnych oraz części biżuterii i wyrobów jubilerskich, cyfrowych aparatów fotograficznych.

Ograniczeniu oszustw w podatku od towarów i usług służy także dalsze zróżnicowanie od 1 stycznia 2016r. stawek odsetek za zwłokę. Obniżono wówczas stawkę odsetek za zwłokę, do wysokości 50\% stawki podstawowej, dla podatników przejawiających inicjatywę w skorygowaniu nieprawidłowości w pierwotnej deklaracji i bezzwłocznym uregulowaniu zaległości podatkowej, przy równoczesnym ograniczeniu czasowym do 6 miesięcy możliwości składania korekty deklaracji uprawniającej do obniżonej stawki odsetek. Ponadto podwyższono stawkę odsetek za zwłokę do wysokości $150 \%$ stawki podstawowej dla podatników podatku od towarów i usług oraz podatku akcyzowego, którzy bądź nie wywiązują się z obowiązku składania deklaracji, bądź zaniżają wysokość deklarowanego zobowiązania (zawyżają wysokość nadpłaty/zwrotu podatku) o ponad 25\% kwoty należnej i wyższej niż pięciokrotna wysokość minimalnego wynagrodzenia w rozumieniu Ustawy z dnia 10 października 2002 r. o minimalnym wynagrodzeniu za pracę ${ }^{31}$. Zmiany te mają służyć upowszechnieniu dobrowolnego i rzetelnego wypełniania obowiązków podatkowych poprzez - z jednej strony - wzmocnienie bodźców stymulujących podatników do jak najszybszego ujawnienia nieprawidłowości w złożonej deklaracji i uregulowania powstałej z tego tytułu zaległości, z drugiej zaś - zwiększenie dolegliwości finansowej wobec uchylania się od obowiązku składania deklaracji oraz znacznego zaniżania deklarowanych zobowiązań w obszarach o podwyższonym ryzyku ${ }^{32}$.

Uszczelnieniu systemu podatkowego służy także wprowadzony od 1 lipca $2016 \mathrm{r}$. obowiązek przesyłania przez podatnika, na żądanie organu podatkowego, części lub całości ksiąg podatkowych oraz dowodów księgowych w ustalonym formacie i jednolitej strukturze (jednolity plik kontrolny), co ma na celu wzmocnienie efektywności weryfikacji ksiąg podatkowych i dowodów księgowych, a tym samym sprawniejsze wykrywanie oszustw, szczególnie w podatku od towarów i usług ${ }^{33}$.

Usprawnieniu postępowań podatkowych służy natomiast wprowadzona od 1 stycznia 2016 r. możliwość zwrócenia się przez organ podatkowy do strony postępowania

31 Art. 56a i 56b Ustawy z dnia 29 sierpnia 1997 r. Ordynacja podatkowa, tekst jedn., DzU 2015, poz. 613 ze zm.

32 Druk nr 3462 z 2.06.2015 r., Rządowy projekt ustawy o zmianie ustawy - Ordynacja podatkowa oraz niektórych innych ustaw, s. 38.

33 Art. 193a Ustawy z dnia 29 sierpnia 1997 r., op.cit. 
o przetłumaczenie na język polski, na własny koszt, przedłożonych przez nią dokumentów sporządzonych w języku obcym ${ }^{34}$.

$\mathrm{Z}$ dniem 8 września $2016 \mathrm{r}$. weszły w życie zmiany przepisów o postępowaniu egzekucyjnym, umożliwiające dokonywanie zajęć rachunków bankowych z użyciem środków komunikacji elektronicznej ${ }^{35}$.

Działania o charakterze organizacyjnym wyrażają się nie tylko w usprawnieniu organizacji pracy organów podatkowych i skarbowych, co częściowo zostało już uwzględnione w zmianach legislacyjnych, lecz także we współpracy wielu służb, organów i instytucji, zarówno krajowych, jak i zagranicznych. Współpraca ta jest niezbędna w celu skutecznego zwalczania przestępczości gospodarczej, w tym podatkowej. Przykładem takich działań jest zawarte 30 stycznia 2014 r. porozumienie Ministra Spraw Wewnętrznych, Ministra Finansów i Prokuratora Generalnego o współpracy w zakresie wypracowania systemowych rozwiązań w odniesieniu do przeciwdziałania i zwalczania przestępczości gospodarczej. Strony tego porozumienia powołały przy tym Zespół ekspercki do spraw przestępczości w zakresie podatku od towarów i usług oraz akcyzy. Jego podstawowym zadaniem jest opracowanie kierunków zmian prawnych służących wzmocnieniu mechanizmów przeciwdziałania przestępczości podatkowej, a także ograniczeniu strat budżetu państwa w związku z tego rodzaju przestępstwami. W celu zwalczania przestępczości związanej z wyłudzeniami nienależnych zwrotów VAT i unikaniem akcyzy Polska współpracuje z: Europejskim Urzędem Policji, Europejskim Urzędem ds. Zwalczania Nadużyć Finansowych, Europejską Jednostką Współpracy Sądowej, pod której egidą tworzony jest, z polskim udziałem, Międzynarodowy Zespół Śledczy, a także z państwami członkowskimi UE (w ramach sieci wymiany informacji - EUROFISC). W 2014r. wdrożona została również interaktywna platforma informacyjna o podmiotach podejrzewanych o udział w oszustwach w podatku od towarów i usług w handlu wewnątrzwspólnotowym o nazwie POLFISC, która ma na celu poprawę skuteczności rozpoznawania i eliminacji oszustw podatkowych w całym kraju ${ }^{36}$. Wyrazem zainicjowania takiej współpracy są także zawarte w 2014 r. porozumienia w sprawie współdziałania między Generalnym Inspektorem Kontroli Skarbowej i Komendantem - Rektorem Wyższej Szkoły Policji w Szczytnie oraz Szefem Centralnego Biura Antykorupcyjnego ${ }^{37}$.

34 Art. 189 \$3 Ustawy z dnia 29 sierpnia 1997 r., op.cit. Takie prawo przysługiwało już wcześniej w przypadku kontroli podatkowej oraz w postępowaniu kontrolnym prowadzonym przez organy kontroli skarbowej. Druk nr 3462 z 2.06.2015 r., op.cit., s. 92.

35 Art. 86b Ustawy z dnia 17 czerwca 1966 r., op.cit.

36 MSW, Raport o stanie..., 2015, op.cit., s. 183 i 184.

37 NIK, Informacja o wynikach..., 2016, op.cit., s. 32. 
W urzędach kontroli skarbowej nastąpiła centralizacja procesów analitycznych i specjalizacja tych urzędów w zwalczaniu oszustw w poszczególnych branżach, w tym dla obszarów: paliwa, wyroby stalowe, elektronika, złom, obrót wewnątrzwspólnotowy, wirtualne biura, obrót spółkami i handel kosztami ${ }^{38}$.

Podejmowane są również działania o charakterze prewencyjnym. Przykładem jest publikacja „listów ostrzegawczych”, opracowywanych przez Ministerstwo Finansów we współpracy z Ministerstwem Rozwoju (dawniej Gospodarki). Listy te przyjmują formę „komunikatów ostrzegawczych”, dotyczących wskazanych branż narażonych na oszustwa w zakresie podatku od towarów i usług ${ }^{39}$. Do takich działań należy także akcja edukacyjna Ministerstwa Finansów - Narodowa Loteria Paragonowa, która ma uświadomić Polakom ich rolę w kształtowaniu uczciwego obrotu gospodarczego.

Ministerstwo Finansów w celu poprawy ściągalności dochodów publicznych, w tym zmniejszenia luki w podatku od towarów i usług, planuje dalsze działania ${ }^{40}$ :

- wprowadzenie do polskiego systemu prawnego klauzuli obejścia prawa podatkowego,

- kontrolę cen transferowych,

- zmiany systemowe, w tym w podatku od towarów i usług,

- rozwój rozwiązań informatycznych,

- reformę administracji skarbowej i powstanie Krajowej Administracji Skarbowej,

- objęcie odpowiedzialnością solidarną za niezapłacony podatek od towarów i usług od importu agencji celnych (obecnie dotyczy ona tylko przedstawicieli pośrednich, którzy działają we własnym imieniu, lecz na rzecz innej osoby; nie dotyczy natomiast przedstawicieli bezpośrednich, którzy działają w imieniu i na rzecz innej osoby ${ }^{41}$.

W celu poprawy efektywności egzekucji podatku od towarów i usług postuluje się wprowadzenia jeszcze takich rozwiązań, jak ${ }^{42}$ :

- obowiązek wystawiania faktur VAT za pośrednictwem serwera Ministerstwa Finansów (centralny rejestr faktur),

- publiczny rejestr rachunków bankowych podatników,

- ograniczenie możliwości rozliczeń kwartalnych w VAT,

- powszechna standaryzacja ewidencji danych (dotyczących dokumentów, księgowań, płatności),

38 MSW, Raport o stanie..., 2015, op.cit., s. 185.

39 Pierwszy taki list o zagrożeniach oszustwami podatkowymi w obrocie elektroniką został opublikowany 25 sierpnia 2014 r., a drugi - o zagrożeniach w obrocie paliwami - w dniu 13 listopada 2014 r.

40 Odpowiedź z dnia 15.01.2016r. Ministra Finansów Pawła Szałamachy na interpelację nr 253 w sprawie założeń i kierunków planowanych działań Ministerstwa Finansów w VIII kadencji Sejmu, http://www. sejm.gov.pl/sejm8.nsf/interpelacja.xsp?typ=INT\&nr=253 [dostęp 17.05.2016].

41 Art. 33a ust. 8 Ustawy z dnia 11 marca 2004 r., op.cit.

42 NIK, Informacja o wynikach..., 2016, op.cit., s. 13 i 14. 
- dodanie kolejnych przesłanek warunkujących wykreślenie podatnika z rejestru podatników VAT,

- fakultatywny split payment ${ }^{43}$ lub możliwość stosowania rozwiązania dzielonej płatności jako przesłanki zwalniającej od odpowiedzialności solidarnej,

- rozszerzenie zakresu odpowiedzialności solidarnej w ten sposób, że będzie miała zastosowanie zawsze $\mathrm{w}$ przypadku dokonywania płatności z tytułu transakcji na konto inne niż uwidocznione w bazie on-line podatników jako konto właściwe do rozliczeń VAT,

- ograniczenie płatności gotówkowych.

\section{Podsumowanie}

Podatek od towarów i usług jest najwydajniejszym podatkiem w Polsce, stanowiącym przeciętnie blisko $41 \%$ dochodów budżetu państwa. Jego wydajność fiskalna jest jednak poważnie zagrożona przez rozpowszechnione w nim oszustwa podatkowe. W ostatnich latach wprowadzono wiele rozwiązań służących ograniczeniu oszustw podatkowych, w szczególności w rozpatrywanym podatku. Niestety, stanowią one narzędzie o ograniczonej efektywności.

Zarówno mechanizm odwrotnego obciążenia wprowadzony w 2011 r., a następnie rozszerzony w latach 2013 i 2015, jak i instytucja solidarnej odpowiedzialności podatkowej wprowadzona w 2013 r. i rozszerzona w 2015 r. doprowadziły do zmniejszenia oszustw w niektórych branżach, nie rozwiązały jednak problemu oszustw w VAT w sposób systemowy. Trzeba bowiem brać pod uwagę możliwe przekwalifikowanie się grup przestępczych i zmianę asortymentu wyrobów będących przedmiotem oszustw podatkowych przy wykorzystaniu tych samych mechanizmów przestępstw ${ }^{44}$. Dodatkowo, domniemanie działania $\mathrm{w}$ dobrej wierze w przypadku nabywania towarów objętych mechanizmem solidarnej odpowiedzialności od podmiotów wymienionych w wykazie prowadzonym przez ministra finansów powoduje, że rozwiązanie to jest w praktyce wykorzystywane przez oszustów podatkowych, którzy składają kaucję i uzyskują w ten sposób status „podmiotu zaufanego"45.

\footnotetext{
43 Split payment (dzielona płatność) polega na podziale płatności przez nabywcę w taki sposób, że cena netto wpłacana jest na konto dostawcy, a kwota VAT na specjalny rachunek podatnika będący w dyspozycji organów podatkowych, zwolnienie kwot tam zgromadzonych dokonywane jest przez ten organ czy też subkonto przypisane danemu podatnikowi w ramach rachunku organu podatkowego. Ibidem, s. 5.

44 MSW, Raport o stanie..., 2015, op.cit., s. 166.

45 NIK, Informacja o wynikach..., 2016, op.cit., s. 25.
} 
Publikowane raporty, przywoływane również w tym artykule, świadczą o tym, że władza publiczna jest świadoma traconych dochodów z podatku od towarów i usług i coraz bardziej zdeterminowana w poprawie skuteczności i efektywności egzekucji tego podatku. Wydaje się jednak, że bez zmian systemowych dotyczących konstrukcji tego podatku wyraźna poprawa jego egzekucji nie jest możliwa. Ponieważ podatek od wartości dodanej jest zharmonizowany w prawie UE, stąd, obok działań na poziomie krajowym, potrzebne są tutaj działania na szczeblu unijnym.

\section{Bibliografia}

CASE, Study to quantify and analyse the VAT Gap in the EU-27 Member States. Final Report, 2013, http://ec.europa.eu/taxation_customs/resources/documents/common/publications/studies/vat-gap.pdf

CASE, 2012 Update Report to the Study to quantify and analyse the VAT Gap in the EU-27 Member States, 2014, http://ec.europa.eu/taxation_customs/resources/documents/common/publications/studies/vat_gap2012.pdf

CASE, Study to quantify and analyse the VAT Gap in the EU Member States. 2015 Report, 2015, http://ec.europa.eu/taxation_customs/resources/documents/common/publications/studies/vat_gap2013.pdf

Druk nr 3462 z 02.06.2015 r., Rządowy projekt ustawy o zmianie ustawy - Ordynacja podatkowa oraz niektórych innych ustaw.

EU, The Concept of Tax Gaps. Report on VAT Gap Estimations by Fiscalis Tax Gap Project Group (FPG/041), 2016, http://ec.europa.eu/taxation_customs/resources/documents/ common/publications/studies/tgpg_report_en.pdf

Informacja o działaniach podjętych przez Polskę w celu realizacji rekomendacji Rady w ramach procedury nadmiernego deficytu. Załacznik 2 - Działania zwiększajace stopień przestrzegania przepisów podatkowych i poprawiajace efektywność administracji podatkowej w latach 2014-2017, http://www.mf.gov.pl/documents/764034/1002171/EDP+raport+2014.04.pdf

IRS, Understanding the Tax Gap, 2005, https://www.irs.gov/uac/understanding-the-tax-gap

Juja T., Wydajność fiskalna podatku od towarów i ustug w latach 2001-2007, w: Wspótczesne finanse. Stan i perspektywy rozwoju finansów publicznych, red. J. Głuchowski, Wydawnictwo UMK, Toruń 2008.

Ministerstwo Finansów, Sprawozdanie z działalności kontroli skarbowej za 2015 rok, Warszawa 2016.

MSW, Raport o stanie bezpieczeństwa w Polsce w 2011 roku, 2012, https://bip.mswia.gov. $\mathrm{pl} / \mathrm{bip} /$ raport-o-stanie-bezpie/18405, Raport-o-stanie-bezpieczenstwa.html 
MSW, Raport o stanie bezpieczeństwa w Polsce w 2012 roku, 2013, https://bip.mswia.gov. $\mathrm{pl} /$ bip/raport-o-stanie-bezpie/18405, Raport-o-stanie-bezpieczenstwa.html

MSW, Raport o stanie bezpieczeństwa w Polsce w 2013 roku, 2014, https://bip.mswia.gov. $\mathrm{pl} /$ bip/raport-o-stanie-bezpie/18405, Raport-o-stanie-bezpieczenstwa.html

MSW, Raport o stanie bezpieczeństwa w Polsce w 2014 roku, 2015, https://bip.mswia.gov. pl/bip/raport-o-stanie-bezpie/18405, Raport-o-stanie-bezpieczenstwa.html

NIK Delegatura w Kielcach, Wystąienie pokontrolne (Numer i tytuł kontroli: K/14/009 - Egzekwowanie obowiazków podatkowych i celnych od podmiotów prowadzacych handel internetowy), LKI-4111-01-03/2014, Kielce 2014.

NIK, Informacja o wynikach kontroli opodatkowania transakcji wewnatrzwspólnotowych podatkiem od towarów i usług oraz egzekwowania zalegtości w VAT, $\mathrm{Nr}$ ewid. 16/2010/P09023/KBF, Warszawa 2010.

NIK, Egzekwowanie należności podatkowych i celnych przez izby celne, $\mathrm{Nr}$ ewid. 48/2013/ P12037/KBF, Warszawa 2013.

NIK, Informacja o wynikach kontroli Sprawność działania stużb państwowych na wybranych przejściach granicznych na granicy wschodniej RP, Nr ewid. 207/2014/P14/108/LRZ, Warszawa 2015.

NIK, Informacja o wynikach kontroli Przeciwdziałanie wprowadzaniu do obrotu gospodarczego faktur dokumentujących czynności fikcyjne, Nr ewid. 24/2016/P/15/011/KBF, Warszawa 2016.

Odpowiedź z dnia 5.10.2012 r. Pana Macieja Grabowskiego podsekretarza stanu w Ministerstwie Finansów - z upoważnienia ministra - na interpelację nr 8642 w sprawie luki podatkowej w podatku od towarów i usług oraz strat finansowych w związku z nią poniesionych, http://sejm.gov.pl/sejm7.nsf/interpelacja.xsp?typ=INT\&nr=8642\&view=null

Odpowiedź z dnia 15.01.2016r. Ministra Finansów Pawła Szałamachy na interpelację nr 253 w sprawie założeń i kierunków planowanych działań Ministerstwa Finansów w VIII kadencji Sejmu, http://www.sejm.gov.pl/sejm8.nsf/interpelacja.xsp?typ=INT\&nr=253

PWC i IBS, Straty Skarbu Państwa w VAT (maj 2013 roku), www.pwc.pl/pl/publikacje/assets/pwc_straty_skarbu_panstwa_w_vat.pdf

Schneider F., Raczkowski K., Sfera nieoficjalna w gospodarce, „Infos” 2013, nr 21.

Ustawa $\mathrm{z}$ dnia 17 czerwca $1966 \mathrm{r}$. o postępowaniu egzekucyjnym w administracji, tekst jedn., DzU 2014, poz. 1619 ze zm.

Ustawa z dnia 29 sierpnia 1997 r. Ordynacja podatkowa, tekst jedn., DzU 2015, poz. 613 ze zm.

Ustawa z dnia 11 marca 2004 r. o podatku od towarów i usług, tekst jedn., DzU 2011, $\mathrm{nr} 177$, poz. 1054 ze zm. 


\section{Gap in the tax on goods and services and the reduction methods}

The study focuses on the concept and components of the tax gap. In addition, the article presents an estimate of the gap in the value added tax in the European Union for the years 2000-2013. With regard to the Poland, it also identifies the causes of the gap occurrence and actions aimed at reducing its size.

Keywords: tax on goods and services, VAT, tax gap, tax evasion

\section{L'écart dans la taxe sur les biens et services, et les méthodes de sa reduction}

Dans l'article, l'auteure se concentre sur le concept et les composants de l'écart fiscal. De plus, elle présente une estimation de cet écart dans la taxe sur la valeur ajoutée dans l'Union Européenne entre 2000 et 2013. En ce qui concerne la Pologne, elle a déterminé les causes de cet écart, ainsi que les démarches ayant pour l'objectif de réduire sa taille.

Mots-clés: taxe sur les biens et services, TVA, écart fiscal, fraude fiscale

\section{Налоговый разрыв по НДС и методы его сокращения}

Основное внимание в исследовании уделено концепции налогового разрыва и его компонентам. В статье проведена оценка налогового разрыва по НДС в Европейском Союзе в 2000-2013 гг. Дополнительно, в отношении Польши представлены причины его возникновения, а также действия, направленные на уменьшение его размера.

Ключевые слова: налог на добавленную стоимость, НДС, налоговый разрыв, уклонение от уплаты налогов 